\title{
KNEE ISOKINETIC TORQUE IMBALANCE IN FEMALE FUTSAL PLAYERS
}

DESEQUILÍBRIO DO TORQUE ISOCINÉTICO DO JOELHO EM JOGADORAS DE FUTSAL FEMININO

DESEQUILIBRIO DEL TORQUEISOCINÉTICO DE LARODILLAEN JUGADORAS DE FUTSAL FEMENINO

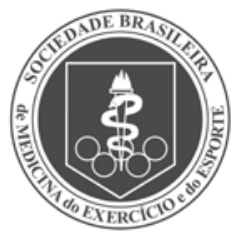

Original Article ARTIGo ORIGINAL Artículo Original
Ana Carolina de Mello Alves Rodrigues ${ }^{1}$ (Physiotherapist) Nathália Arnosti Vieira' (Physical Education Professional) Ana Lorena Marche ${ }^{1}$ (Physical Education Professional) Juliana Exel Santana (Physical Education Professional) Marco Aurélio Vaz ${ }^{2}$ (Physical Education Professional) Sergio Augusto Cunha' (Physical Education Professional)

1. Universidade Estadual de Campinas (UNICAMP), Escola de Educação Física, Laboratório de Instrumentação para Biomecânica, Campinas, SP, Brazil.

2. Universidade Federal do Rio Grande do Sul, Escola de Educação Física, Fisioterapia e Dança, Porto Alegre, RS, Brazil.

\section{Correspondence:}

Av. Érico Veríssimo, 701, Cidade Universitária Zeferino Vaz, Barão Geraldo, Campinas, SP, Brazil. acmarodrigues@gmail.com

\section{ABSTRACT}

Introduction: The specificity of sports training can lead to muscle specialization with a possible change in the natural hamstring/quadriceps torque ratio ( $\mathrm{HQ}$ ratio), constituting a risk factor for muscle injury at the joint angles in which muscle imbalance may impair dynamic stability. Objective: The aim was to evaluate the torque distribution of the hamstrings and quadriceps and the HQ ratio throughout the range of motion in order to identify possible muscle imbalances at the knee of female futsal athletes. Methods: Nineteen amateur female futsal athletes had their dominant limb HQ ratio evaluated in a series of five maximum repetitions of flexion/extension of the knee at $180^{\circ}$ /second in the total joint range of motion $\left(30^{\circ}\right.$ to $\left.80^{\circ}\right)$. The peak flexor and extensor torque and the $\mathrm{HQ}$ ratio (\%) were compared each $5^{\circ}$ of knee motion using one-way repeated measures ANOVA and Tukey's post hoc test $(p<0.05)$ to determine the joint angles that present muscular imbalance. Results: Quadriceps torque was higher than $50^{\circ}$ to $60^{\circ}$ of knee flexion, while hamstrings torque was higher than $55^{\circ}$ to $65^{\circ}$. The $\mathrm{HQ}$ ratio presented lower values than $30^{\circ}$ to $45^{\circ}$ of knee flexion and four athletes presented values lower than $60 \%$, which may represent a risk of injury. However, the HQ ratio calculated by the peak torque showed only one athlete with less than $60 \%$. Conclusion: The $\mathrm{HQ}$ ratio analyzed throughout the knee range of motion allowed identifying muscle imbalance at specific joint angles in female futsal players.

Keywords: torque; soccer; knee joint; muscle, skeletal/physiopathology.

\section{RESUMO}

Introdução: A especificidade do treinamento esportivo pode levar à especialização muscular, com possivel alteração da razão do torque isquiotibiais/quadríceps (razão IQ) natural, constituindo um fator de risco de lesão muscular nos ângulos articulares em que o desequilíbrio muscular pode prejudicar a estabilidade dinâmica. Objetivo: O objetivo foi avaliar a distribuição do torque dos músculos isquiotibiais e quadríceps e da razão IQ ao longo de toda a amplitude de movimento, de modo a identificar possiveis desequilibrios musculares no joelho de atletas de futsal feminino. Métodos: Dezenove atletas amadoras de futsal feminino tiveram a razão $1 Q$ do membro dominante avaliada em uma série de cinco repetições máximas de flexão/extensão do joelho a 180\% segundo na amplitude de movimento total $\left(30^{\circ}\right.$ a $\left.80^{\circ}\right)$. O pico de torque flexor e extensor e a razão IQ (\%) foram comparados a cada $5^{\circ}$ de movimento do joel ho pela one-way ANOVA de medidas repetidas e do teste post hoc de Tukey $(p<0,05)$ para determinar os ângulos articulares que apresentam desequilibrio muscular. Resultados: O torque do quadríceps foi maior que $50^{\circ}$ a $60^{\circ}$ de flexão do joelho, enquanto o torque dos isquiotibiais foi maior que $55^{\circ}$ a $65^{\circ}$. A razão $1 Q$ apresentou menores valores que $30^{\circ}$ a $45^{\circ}$ de flexão do joel ho e quatro atletas apresentaram valores abaixo de 60\%, o que pode representar risco de lesão. No entanto, a razão IQ calculada pelo pico de torque mostrou apenas uma atleta com menos de 60\%. Conclusão: A razão IQ analisada ao longo de toda a amplitude de movimento permitiu identificar desequilibrio muscular em ângulos articulares especificos em atletas de futsal feminino.

Descritores: torque; futebol; articulação do joelho; músculo esquelético/fisiopatologia.

\section{RESUMEN}

Introducción: La especificidad del entrenamiento deportivo puedellevar a la especialización muscular, con posible cambio de la razón de torque entre isquiotibiales/cuádriceps (razón IC) natural, constituyendo un factor de riesgo de lesión muscular en los ángulos de las articulaciones, en el que el desequilibrio muscular puede perjudicar la estabilidad dinámica. Objetivo; El objetivo fue evaluar la distribución del torque de los músculos isquiotibiales y cuádriceps y la razón IC a lo largo de todo el rango de movimiento para identificar posibles desequilibrios musculares en la rodilla en atletas de futsal femenino. Métodos: Diecinueve atletas amateurs de futsal femenino tuvieron la razón IC de la extremidad dominante evaluada en una serie de cinco repeticiones máximas de flexión/extensión de la rodilla a $180^{\circ}$ /segundo en el rango de movimiento total $\left(30^{\circ}\right.$ a $\left.80^{\circ}\right)$. El pico de torque flexor y extensor y la razón IC (\%) fueron comparados a cada $5^{\circ}$ de movimiento de la rodilla por el ANOVA one-way de medidas repetidas y de la prueba post hoc de Tukey $(p<0,05)$ para determinar los ángulos articulares que presentan desequilibrio muscular. Resultados: El torque del cuádriceps fue mayor que 
$50^{\circ}$ a $60^{\circ}$ de flexión de la rodilla, mientras que el torque de los isquiotibiales fue mayor que $55^{\circ}$ a $65^{\circ}$. La razón IC presentó los valores más bajos que $30^{\circ}$ a $45^{\circ}$ de flexión de la rodilla y cuatro atletas presentaron valores inferiores al 60\%, lo que puede representar riesgo de lesión. Sin embargo, la razón IC calculada por el pico de torque máximo, mostró sólo una atleta con menos del 60\%. Conclusión. La razón IC analizada a lo largo de todo el rango de movimiento permitió identificar desequilibrio muscular en ángulos articulares específicos en atletas de futsal femenino.

\section{Descriptores: torque; fútbol; articulación de la rodilla; músculo esquelético/fisiopatología.}

\section{INTRODUCTION}

In team sports ${ }^{1,2}$ as futsal, muscle force imbalance is a common phenomenon due to the specific demands associated with sports practice because of knee extensors predominant use compared to knee flexors ${ }^{3,4}$. In females, there is a greater quadriceps activation and decreased hamstrings co-activation due to hormonal factors, along with specific demands of the extensor of the dominant limb, which can increase muscle imbalance between opposing (agonists and antagonists) muscles ${ }^{5-8}$. The hamstrings/quadriceps peak torque ratio ( $\mathrm{HQ}$ ratio) is an index used to evaluate the stabilizing efficiency of the knee joint muscles ${ }^{9,10}$. Specifically, it measures the ability of the hamstrings to neutralize tibial anterior translational forces produced by the knee extensors, providing dynamic joint stability during knee extension ${ }^{9-11}$. It is well established that the $\mathrm{HQ}$ physiological peak torque ratio is $60 \%$ on average, representing the level of muscular balance. This value is an overall average based on many different studies using different dynamometers ${ }^{1,2}$, different genders ${ }^{1,2}$, specific populations such as athletes ${ }^{12,13}$, physically active subjects ${ }^{1,2}$, and patients pre-post anterior cruciate ligament $(A C L)$ reconstruction ${ }^{1,2}$. Because of this, the use of this conventional ratio as a normative value has gained general acceptance ${ }^{14-17}$.

However, knee dynamic stability may be compromised even within this $60 \%$ ratio ${ }^{18,19}$. Although the $\mathrm{HQ}$ ratio provides means to evaluate the likelihood of injuries, this ratio is often calculated using the peak torque achieved by the hamstrings and quadriceps during isokinetic tests, independent of angle and time. Consequently, torque production changes throughout the entire joint range of motion are not taken into consideration. Hiemstra et al..$^{20}$ analyzed the work produced by the knee flexors and extensors in a joint range of motion from $5^{\circ}$ to $95^{\circ}$ of knee flexion in 10 different sagittal angular velocities. Although both muscular groups can present a similar area under the torque-angle curve displaying a similar work, the amplitude and instant at which the peak torque occurs differs between the hamstrings and quadriceps muscles, and muscle imbalances can occur at specific joint angles that might overload some joint structures.

The force produced by skeletal muscles depends on their length, and is influenced by anatomical parameters such as muscle architecture, tissue elasticity and joint geometry. In other words, muscle force production is muscle-length dependent and therefore different torques are produce at different joint angles ${ }^{21,22}$. In addition, muscle architecture changes depending on the training specificity of different sports modalities and activities, thereby changing the normal $\mathrm{HQ}$ ratio and the joint angle where peak torque occurs.

Therefore, to better understand the $\mathrm{HQ}$ ratio it is important to analyze this parameter throughout the total joint range of motion. Using this rationale, the $\mathrm{HQ}$ ratio should be evaluated at the same joint angles at which hamstrings and quadriceps torque values are obtained in order to assess possible adaptations in this ratio due to sports training. This is essential to assess the thigh muscles' force production capacity to control the dynamic stability during motion in the sagittal plane. Thus, the aim of this study was to evaluate the HQ ratio in female futsal athletes in order to identify possible muscle imbalances throughout the knee flexion/extension range of motion. Our hypothesis is that female futsal athletes have higher muscle imbalance when compared to male athletes imbalance described in the literature due to a combination of functional demands of these muscle groups and decreasing hamstrings co-activation due to hormonal factors.

\section{METHODS}

Nineteen amateur female futsal athletes aged $21 \pm 2.8$ years (mean \pm SD), with no reported pathology on lower-limb muscles, with no contra-indication to perform maximal effort, and at least five years of futsal practice participated in the study. All participants were informed about the procedures, requirements, risks and benefits before signing a consent form to participate in the study, which was approved by University's local ethics committee ( $\left.n^{\circ} 1201 / 2010-C E P\right)$.

An isokinetic dynamometer (Biodex Medical Systems 3, New York, USA), with a sampling frequency of $100 \mathrm{~Hz}$, was used to obtain torque data during the maximal voluntary contractions of the athletes' dominant limb, established as the lower-limb mostly used to kick the ball. Subjects were seated on the dynamometer chair and had the dominant hip, thigh, and tibia stabilized by straps. The knee joint axis of rotation was aligned with the dynamometer's axis of rotation. Quadriceps and hamstrings muscle torques were evaluated concentrically, with the knee range of motion established from $90^{\circ}$ to $0^{\circ}$ of knee flexion $\left(0^{\circ}=\right.$ full knee extension). Gravity effect was corrected automatically by the dynamometer software.

Participants went through a familiarization procedure aimed at providing the athletes with a previous experience of the maximal effort test. Before the test, athletes had a five-minute warm-up trial on a cycle ergometer, cycling at their preferred cadence. Evaluation was performed through one set of five knee flexion and extension repetitions at an angular velocity of $180^{\circ}$ s, which was chosen based on a study that showed a relationship between torque produced at this velocity and jump performance ${ }^{18,23}$. The repetition with the highest torque value over the five repetitions of knee flexion and extension was considered for analysis.

The data obtained were analyzed through specific routines developed in Matlab ${ }^{\circledR}$, which was also used for all statistical procedures. All data were filtered by $4^{\text {th }}$ order Butterworth low-pass filter with a cutoff frequency of $2 \mathrm{~Hz}$, determined by spectral analysis performed previously.

The acceleration and deceleration phases (beginning and end of the motion amplitude) were excluded to eliminate the torque that was not generated in an isokinetic condition ${ }^{24,25}$. Thus, the corrected isokinetic joint range of motion ranged from $30^{\circ}$ to $80^{\circ}$ and was normalized in order to facilitate the results interpretation. This range of motion has been reported as the optimal range for quadriceps and hamstrings peak torque production $\left(71.3^{\circ} \text { and } 30.1^{\circ} \text {, respectively }\right)^{26}$. 
The normalized $\mathrm{HQ}$ ratio (\%) was determined based on the torque values of torque-angle curves $\left(30^{\circ}\right.$ to $\left.80^{\circ}\right)$ from each muscle group. The ratio was calculated by dividing the hamstrings torque values by the quadriceps torque values throughout the range of motion. The specific ratio measures were obtained every five degrees of the total range of motion (from $30^{\circ}$ to $80^{\circ}$ of knee flexion), so that the pattern of the $\mathrm{HQ}$ ratio distribution could be better characterized and specific angles in which the ratio was under $60 \%$ could be determined. HQ ratio values below this threshold indicated that the natural balance between hamstrings and quadriceps was disrupted ${ }^{14-17}$.

Data normality was tested using the Lilliefors test. To compare the $\mathrm{HQ}$ torque ratio among the different knee angles at each $10 \%$ of the motion cycle, a one-way repeated measures ANOVA was used. A pairwise comparison was done using the Tukey post hoc test. Data are presented in mean \pm standard deviation values $(P<0.05)$.

\section{RESULTS}

Mean quadriceps torque values were higher from $50^{\circ}$ to $60^{\circ}$ of knee flexion compared to the other joint angles of the total range of motion, whereas the mean hamstrings torque was higher from $55^{\circ}$ to $65^{\circ}$ of knee flexion (Figure 1).

On average, $\mathrm{HQ}$ ratio presented a pattern in its distribution with lower values at $30^{\circ}$ to $45^{\circ}$ and higher values at $65^{\circ}$ to $80^{\circ}$ of knee flexion, respectively (Figure 2). The obtained mean $\mathrm{HQ}$ ratio values were above $60 \%$ for the entire range of motion, which reflected the presence of muscle imbalance, with values between $70 \%$ to $90 \%$.

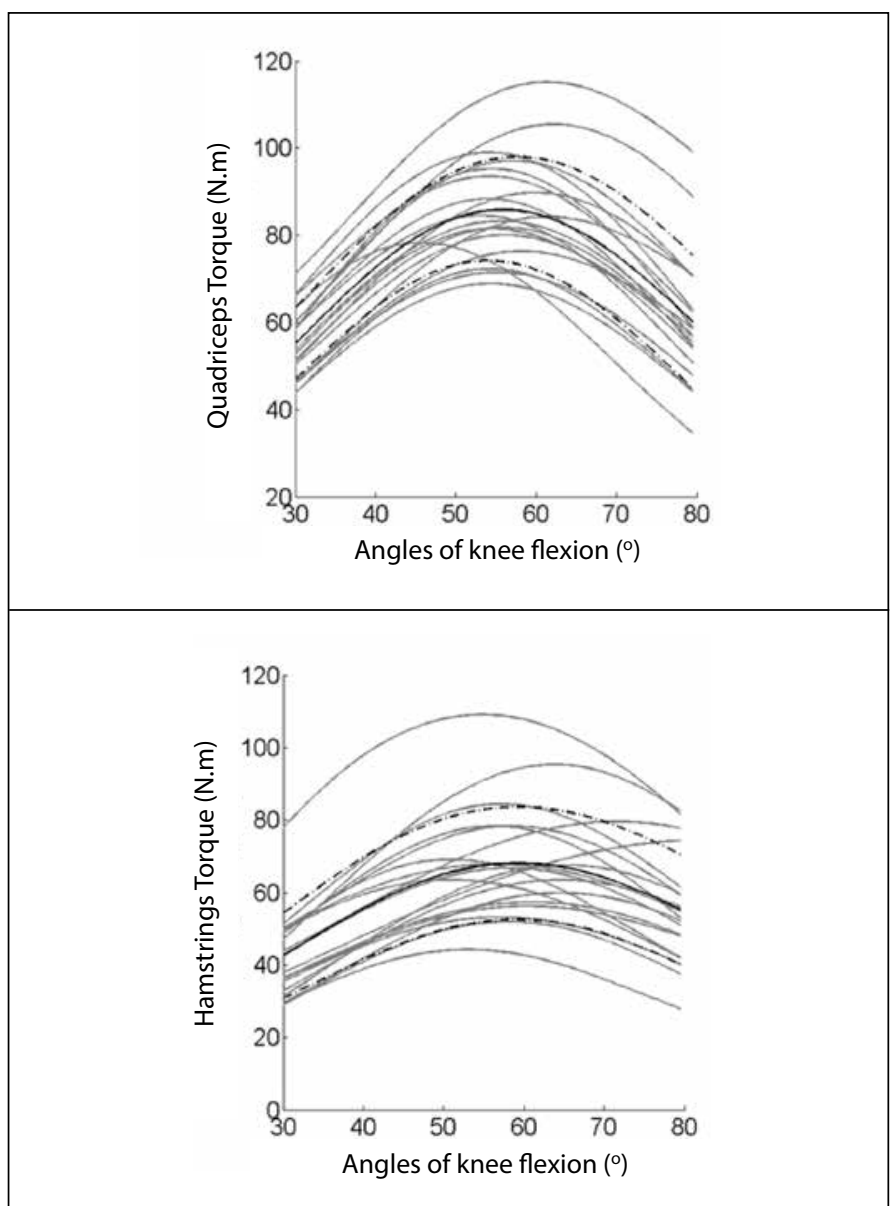

Figure 1. Quadriceps and hamstrings torque of the dominant limb of amateur female futsal players measured from $30^{\circ}$ to $80^{\circ}$ of knee flexion. Torque was measured during isokinetic test at the angular velocity of $180 \%$ s. Gray solid lines represent individual torque measures of the 19 players in each situation. Solid and dotted black lines represent group mean and standard deviation, respectively.
When the $\mathrm{HQ}$ ratio obtained for each $5^{\circ}$ of knee flexion was compared among the different joint angles throughout the entire range of motion, significantly higher values were found at the highest degrees of knee flexion $\left(70^{\circ}\right.$ to $\left.80^{\circ}, \mathrm{p}<0.001\right)$ compared to the $30-35^{\circ}$ of knee flexion (Figure 3).

Interestingly, when the mean $\mathrm{HQ}$ ratio produced by the athletes was examined at each $5^{\circ}$ angle (from $30^{\circ}$ to $80^{\circ}$ of knee flexion), four athletes presented $\mathrm{HQ}$ ratios below the $60 \%$ threshold, although on average the $\mathrm{HQ}$ ratio was above this percentage level. When looking at the conventional $\mathrm{HQ}$ ratio that uses just the peak torque values, only one athlete was under the $60 \%$ ratio threshold, as can be verified at the underlined data of Table 1. As the angle of peak torque differs between the hamstrings and the quadriceps muscles, the conventional peak torque $\mathrm{HQ}$ ratio was obtained using peak torque values from the optimal muscle lengths.

\section{DISCUSSION}

The main outcome of the present study is that the $\mathrm{HQ}$ ratio showed imbalance in force production throughout the entire knee flexion/ extension range of motion. This imbalance is apparently due to some kind of neuromuscular adaptation due to sports practice in female futsal players. Although futsal players prioritize the quadriceps while kicking a ball during training ${ }^{5-8}$, an HQ ratio close to 100\% (or higher than 60\%, the normal ratio value that is said to represent muscle balance) can be due to a decrease in knee extensor torque production, to an increase in knee flexor torque production or to a combination of these two. The

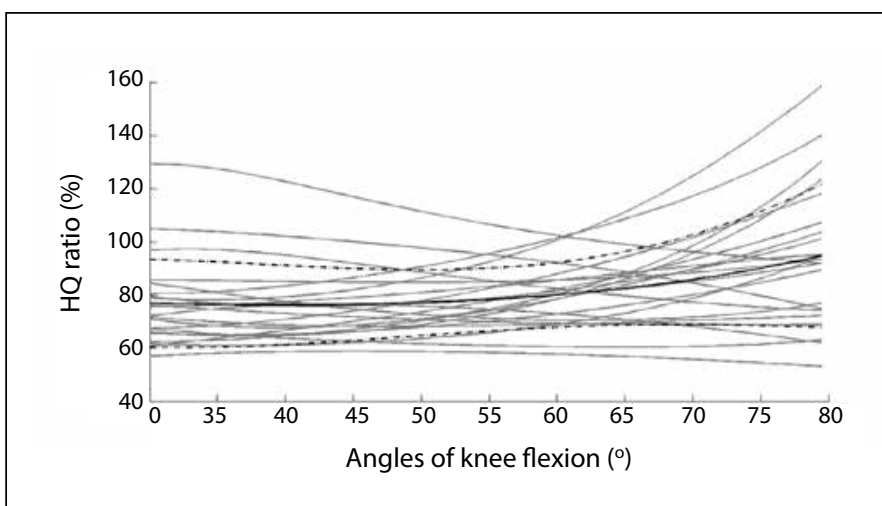

Figure 2. Hamstrings/quadriceps torque ratio ( $\mathrm{HQ}$ ratio) of the dominant limb of amateur female futsal players measured from $30^{\circ}$ to $80^{\circ}$ of knee flexion (angular velocity $=180^{\circ} \mathrm{s}$ ). Gray solid lines represent individual HQ ratio measures of the 19 athletes in each situation. Solid and dotted black lines represent group mean and standard deviation, respectively. The horizontal dotted line at $60 \%$ of HQ represents the threshold ratio below which the injury risk is increased.

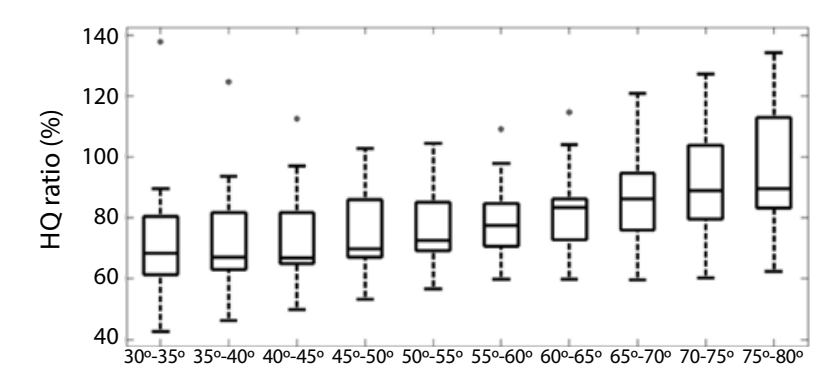

Angles of knee flexion $\left(^{\circ}\right)$

Figure 3. Boxplot of the hamstrings/quadriceps torque ratio (HQ torque ratio) calculated each $5^{\circ}$ of the joint motion $\left(35^{\circ}, 40^{\circ}, 45^{\circ}, 50^{\circ}, 55^{\circ}, 60^{\circ}, 65^{\circ}, 70^{\circ}, 75^{\circ}\right.$ and $80^{\circ}$ of knee flexion) at $180^{\circ} / \mathrm{s}$. + denotes outliers. Boxplots were used for presenting the group values at each joint angle. 
Table 1. Hamstrings/Quadriceps (HQ) torque ratio (\%) for each participant from $30^{\circ}$ to $80^{\circ}$ of isokinetic knee flexion and the respective $\mathrm{HQ}$ peak torque (\%). HQ torque ratio values below $60 \%$ are underlined.

\begin{tabular}{|c|c|c|c|c|c|c|c|c|c|c|c|}
\hline & \multicolumn{10}{|c|}{ Mean HQ ratio (\%) } & \multirow{2}{*}{\begin{tabular}{|c|} 
HQ \\
Peak \\
torque \\
$(\%)$
\end{tabular}} \\
\hline & $30-35^{\circ}$ & $35-40^{\circ}$ & $40-45^{\circ}$ & $45-50^{\circ}$ & $50-55^{\circ}$ & $55-60^{\circ}$ & $60-65^{\circ}$ & $65-70^{\circ}$ & $70-75^{\circ}$ & 75-8 & \\
\hline $\mathrm{S1}$ & 67.77 & 70.05 & 72.85 & 76.14 & 80.01 & 84.58 & 90.04 & 96.63 & 104.61 & 114.26 & 86.93 \\
\hline$\$ 2$ & 71.14 & 76.86 & 82.43 & 87.73 & 92.77 & 97.58 & 102.20 & 106.59 & 110.52 & 2113.46 & 92.93 \\
\hline 53 & 42.66 & $\underline{46.26}$ & 49.82 & $\underline{53.29}$ & $\underline{56.68}$ & $\underline{59.99}$ & 63.27 & 66.50 & 69.64 & 72.51 & $\underline{57.84}$ \\
\hline 54 & 80.62 & 82.54 & 85.29 & 88.73 & 92.89 & 97.89 & 103.98 & 3111.54 & 121.24 & 134.20 & 99.94 \\
\hline 55 & 68.38 & 66.78 & 66.83 & 68.21 & 70.87 & \begin{tabular}{|l|}
74.88 \\
\end{tabular} & 80.47 & 87.98 & 97.87 & 110.66 & 80.33 \\
\hline 56 & \begin{tabular}{|l|}
60.99 \\
\end{tabular} & 61.86 & 63.30 & 65.14 & 67.30 & 69.78 & 72.59 & 75.76 & 79.34 & 83.31 & 68.76 \\
\hline 57 & 65.85 & 65.22 & 66.16 & 68.45 & 72.14 & 77.47 & 84.91 & 95.14 & 109.15 & 128.32 & 89.44 \\
\hline 58 & 137.87 & 124.59 & 112.66 & \begin{tabular}{|l|l|}
5 & 102.87 \\
\end{tabular} & 95.25 & 89.58 & 85.68 & 83.48 & 83.15 & \begin{tabular}{|l|}
85.22 \\
\end{tabular} & 86.58 \\
\hline 59 & 61.23 & 62.98 & 64.79 & 66.71 & 68.82 & 71.20 & 73.96 & 77.16 & 80.84 & 84.93 & 69.63 \\
\hline$S 10$ & $\underline{57.80}$ & 61.48 & 65.53 & .94 & 74.81 & 80.26 & 86.47 & 93.65 & 101.94 & $\begin{array}{l}4111.40 \\
\end{array}$ & 82.56 \\
\hline$S 11$ & 69.88 & 67.13 & 65.61 & 65.05 & 65.31 & 66.34 & 68.15 & 70.84 & 74.53 & 79.28 & 66.56 \\
\hline $\mathrm{S12}$ & \begin{tabular}{|l|}
87.97 \\
\end{tabular} & 82.79 & 78.44 & 74.97 & 72.34 & 70.49 & 69.38 & 68.99 & 69.42 & \begin{tabular}{|l|}
70.84 \\
\end{tabular} & 71.84 \\
\hline 513 & \begin{tabular}{|l|}
75.47 \\
\end{tabular} & 74.62 & 74.81 & 75.81 & 77.56 & \begin{tabular}{|l|l|}
80.10 \\
\end{tabular} & 83.56 & 88.12 & \begin{tabular}{|l|l|}
94.04 \\
\end{tabular} & 101.56 & 80.16 \\
\hline 514 & \begin{tabular}{|l|}
89.58 \\
\end{tabular} & 93.65 & 97.14 & 100.65 & 104.58 & \begin{tabular}{|l|l|}
109.19 \\
\end{tabular} & 114.61 & 120.76 & 127.29 & 133.37 & 103.43 \\
\hline $\mathrm{S15}$ & \begin{tabular}{|l|}
79.72 \\
\end{tabular} & 79.48 & 79.93 & 80.90 & 82.23 & 83.83 & 85.61 & 87.40 & 88.91 & 89.69 & 83.72 \\
\hline $\mathrm{S16}$ & \begin{tabular}{|l|}
66.06 \\
\end{tabular} & 65.23 & 64.07 & 62.80 & 61.59 & \begin{tabular}{|l|l|}
60.56 \\
\end{tabular} & $\underline{59.84}$ & $\underline{59.64}$ & 60.33 & 62.53 & 61.16 \\
\hline$S 17$ & 87.21 & 89.02 & 88.88 & 87.75 & 86.25 & \begin{tabular}{|l|}
84.77 \\
\end{tabular} & 83.53 & 82.73 & 82.56 & 83.27 & 86.28 \\
\hline$S 18$ & $\underline{54.05}$ & $\underline{59.16}$ & 64.02 & 68.54 & 72.72 & 76.56 & 80.07 & 83.10 & 85.38 & 86.39 & 73.26 \\
\hline 519 & 61.48 & 63.44 & 65.87 & 68.71 & 72.02 & \begin{tabular}{|l|}
75.91 \\
\end{tabular} & 80.56 & 86.22 & \begin{tabular}{|l|}
93.22 \\
\end{tabular} & 102.01 & 77.90 \\
\hline$x$ & 72.93 & 73.32 & 74.13 & 75.39 & 77.16 & 79.52 & 82.57 & 86.43 & 91.26 & \begin{tabular}{|l|l|}
97.22 \\
\end{tabular} & 79.96 \\
\hline SD & \pm 19.87 & \pm 16.91 & \pm 14.55 & \pm 13.04 & \pm 12.46 & \pm 12.75 & \pm 13.80 & \pm 15.54 & \pm 18.03 & $3 \pm 21.48$ & \pm 12.32 \\
\hline
\end{tabular}

way this ratio was calculated in the present study provides important information about knee flexor/extensor imbalance along the entire joint range of motion in female futsal players, and might allow for the identification of possible injury risks during this range of motion.

The HQ ratio is frequently used as an index to evaluate the stabilizing efficiency of the knee joint muscles ${ }^{9-11}$. In this study, HQ ratios varied throughout the joint range of motion, with lower values at $30^{\circ}$ to $45^{\circ}$ of knee flexion, and higher values at $65^{\circ}$ to $80^{\circ}$. The low values close to knee extension are associated with two factors: the low quadriceps torque production, in that the mean peak of torque production occurred at $54^{\circ}$ of knee flexion and the decreases in force production capacity of this muscle as a result of the force-length relationship and the mechanical disadvantage of this muscle at full knee extension ${ }^{17}$. That is, the quadriceps muscle is lengthened at the beginning of the motion when the knee is fully flexed and is much shorter with the knee extended to generate power. The other factor is the increased hamstring torque production around $67^{\circ}$ of knee flexion in some athletes. Hamstrings are used around this joint angle in futsal practice, which might explain the need for a higher torque production of this muscle group.

The HQ ratio values can be affected by specific sports demands; therefore, varying values have been reported for different sports modalities (judo, handball and soccer). Apparently, different hormone characteristics also produce sex-specific changes among these athletes on the $\mathrm{HQ}$ ratio ${ }^{7,18}$. Andrade et al..$^{18}$ compared male and female $\mathrm{HQ}$ ratio of handball, football and judo athletes, and found lower values at $60 \%$ for female athletes (judo: $53 \pm 10$, handball: $56 \pm 6$, soccer: $54 \pm 11$ ) compared to male athletes (judo: $57 \pm 14$, handball: $63 \pm 12$, soccer: $66 \pm 12$ ). However higher values were observed at the angular velocity of $180 \%$ for female (judo: $72 \pm 10$, handball: $65 \pm 6$, soccer: $72 \pm 11$ ) compared to male (judo: $69 \pm 8$, handball: $63 \pm 9$, soccer: $68 \pm 12$ ) athletes. These findings are similar to those seen in this study, as the observed values were above $60 \%$ in female futsal players.
Apparently, this higher knee joint muscle strength imbalance has been correlated with a higher injury incidence in females. This lower hamstrings torque in relation to quadriceps torque decreases the female players' ability to control the knee motion at the coronal and sagittal planes, predisposing them to greater lower-limb injury incidence ${ }^{12,18}$. This higher injury risk reinforces the importance of evaluating female athletes maximal torque production throughout the entire joint range of motion between antagonistic muscle groups, as well as the HQ ratio, in order to better understand muscle function and muscle imbalance in these athletes.

Some studies ${ }^{21,27}$ analyzed the $\mathrm{HQ}$ ratio in isometric and isokinetic conditions through mathematical models and specific angles. All studies showed that the HQ ratio values were highly dependent on the tested angle. Nevertheless, the analysis of the $\mathrm{HQ}$ ratio using peak torque values similarly showed the existence of muscle imbalances in professional and amateur athletes of different sports 7,9,12,13,15,19. However, it is not possible to determine if the muscle imbalance was caused by the increase of hamstrings torque or decreased quadriceps torque for these athletes, as the torque production was not evaluated throughout the total knee range of motion in these studies.

Our findings indicate that the analytical approach, based on a single measure of peak torque, may underestimate the real muscle imbalances frequency in athletes. For example, in this study the $\mathrm{HQ}$ ratio using the peak torque revealed that only one athlete was above the $60 \%$ ratio threshold at the angular velocity of $180 \%$ s. However, the $\mathrm{HQ}$ ratio obtained throughout the entire range of motion showed that four athletes had $\mathrm{HQ}$ ratios above this threshold. Therefore, assessing muscle imbalance by the $\mathrm{HQ}$ peak torque ratio neglects the force-length relationship, in which different torque values are produced at different joint angles $21,22,28$. The method here presented detects specific angles of imbalance that can be used to design training programs aimed at decreasing these imbalances in female futsal players.

Hiemstra et al. ${ }^{20,29}$ found similar work (area under the torque-angle curve) results by the knee flexors and extensors from $5^{\circ}$ to $95^{\circ}$ of knee flexion and different angular velocities. However, the amplitude and instant at which the peak torque occurred differs between muscle groups, and they did not identify how the torque was distributed throughout the range of motion between both muscle groups. The present study goes a step beyond in the analysis of knee torque production, detailing and identifying the different ratios along the range of motion, with the angles that have muscle imbalance. This procedure may contribute to improving training sessions and rehabilitation procedures, avoiding possible injury risks and possibly removing athletes from sports practice before these injuries are established.

The angle-specific HQ ratio demonstrated a strong relationship with sports practice that might be related to injury risks. It also allows for a better understanding of dynamic force production and dynamic stability around the knee, as both muscle groups produce torque in the same range of motion to ensure dynamic stability.

This study had some limitations. First, we did not included athletes with lower-limb injuries history, which would add interesting information if their $\mathrm{HQ}$ ratio was compared with healthy athletes. We also did not calculate the functional $\mathrm{HQ}$ ratio. The functional $\mathrm{HQ}$ ratio is widely used in assessing knee muscles imbalance, and differs from the conventional ratio used in this study as it is calculated as the ratio between eccentric hamstrings torque divided by concentric quadriceps torque. This information could give an idea about the torques produced during the kicking motion, where there is concentric quadriceps contraction followed by eccentric hamstrings contraction at the phase where the knee is extending towards the ball contact. 


\section{CONCLUSION}

Female futsal players produced mean $\mathrm{HQ}$ ratio values above $60 \%$ for the entire knee joint range of motion, reflecting the presence of muscle imbalance. The analysis of quadriceps and hamstrings torque values and $\mathrm{HQ}$ ratio throughout the total knee range of motion enables the identification of muscle balance distribution, as well as determining specific angles with lower values of torque production and muscle imbalance in female futsal players. This new methodology may contribute to preventing lower limb injury. Future studies in other settings and populations may prove useful to enhance training and rehabilitation programs, as well as injury prevention.

\section{ACKNOWLEDGMENTS}

The Brazilian National Council of Technological and Scientific Development (CNPq) supported this work. Authors certify that there is no conflict of interest with any financial organization regarding the material discussed in the manuscript.

All authors declare no potential conflict of interest related to this article.

AUTHORS' CONTRIBUTIONS: Each author made significant individual contributions to this manuscript. ACMAR (0000-0002-1722-1737)* conceived the study, acquired and interpreted data, and drafted and reviewed the manuscript. NAV (0000-0002-8245-4844)* ALM (0000-0001-7344-4647)* and JES (0000-0003-4409-7329)* analysed data, and reviewed the manuscript. MAV (0000-0001-6741-3502)* interpreted data, and drafted and reviewed the manuscript. SAC (0000-0003-1927-0142)* conceived the study, acquired and interpreted data, and drafted and reviewed the manuscript. *ORCID (Open Researcher and Contributor ID).

\section{REFERENCES}

1. Ayala F, Baranda PS, Ste Croix M, Sarobe L. Absolute reliability of conventional and functional ratios and peak isokinetic torque of knee flexion and extension. Apunts Med Esport. 2012;47(174):55-64.

2. Ayala F, Baranda PS, Ste Croix M, Santoja F.Validity and reliability of isokinetic strength ratios for estimation of muscle imbalances. Apunts Med Esport. 2012:47(176):131-42.

3. Silva Neto $M$, Simões $R$, Grangeiro Neto JA, Cardone CP. Avaliação isocinética da força muscular em atletas profissionais de futebol feminino. Rev Bras Med Esporte. 2010;16(1):33-5.

4. Weber FS, Silva BGC, Radaelli R, Paiva C, Pinto RS. Avaliação Isocinética em Jogadores de Futebol Profissional e Comparação do Desempenho Entre as Diferentes Posições Ocupadas no Campo. Rev Bras Med Esporte. 2010;16(4):264-8.

5. Alentorn-Geli E, Myer GD, Silvers HJ, Samitier G, Romero D, Lázaro-Haro C, et al. Prevention of non-contact anterior cruciate ligament injuries in soccer players. Part 1: Mechanisms of injury and underlying risk factors. Knee Surg Sports Traumatol Arthrosc. 2009;17(7):705-29.

6. Bennett DR, Blackburn JT, Boling MC, McGrath M, Walusz H, Padua DA. The relationship between anterior tibial shear force during a jump landing task and quadriceps and hamstring strength. Clin Biomech (Bristol, Avon). 2008;23(9):1165-71.

7. Hewett TE, Myer GD, Zazulak BT. Hamstrings to quadriceps peak torque ratios diverge between sexes with increasing isokinetic angular velocity. J Sci Med Sport. 2008;11(5):452-9.

8. Renstrom P, Ljungqvist A, Arendt E, Beynnon B, Fukubayashi T, GarrettW, et al. Non-contact ACL injuries in female athletes: an International Olympic Committee current concepts statement. Br J Sports Med. 2008;42(6):394-412.

9. Aagaard P, Simonsen EB, Magnusson SP, Larsson B, Dyhre-Poulsen P. A new concept for isokinetic hamstring: quadriceps muscle strength ratio. Am J Sports Med. 1998;26(2):231-7.

10. Grygorowicz M, Kubacki J, Pilis W, Gieremek K, Rzepka R. Selected isokinetic tests in knee injury prevention. Biol Sport. 2010;27(1):47-51

11. Daneshjoo A, Mokhtar AH, Rahnama N, Yusof A. The effects of injury preventive warm-up programs on knee strength ratio in young male professional soccer players. PLoS One. 2012;7(12):e50979.

12. Croisier JL, Ganteaume S, Binet J, Genty M, Ferret JM. Strength imbalances and prevention of hamstring injury in professional soccer players: a prospective study. Am J Sports Med. 2008;36(8):1469-75.

13. O'Sullivan $K$, O'Ceallaigh B, O'Connell $K$, Shafat A. The relationship between previous hamstring injury and the concentric isokinetic knee muscle strength of Irish Gaelic footballers. BMC Musculoskelet Disord. 2008;9:30

14. Cabri JM, Clarys JP. Isokinetic exercise in rehabilitation. Appl Ergon. 1991;22(5):295-8.
15. Coombs R, Garbutt G. Developments in the Use of the Hamstring/Quadriceps Ratio for the Assessment of Muscle Balance. J Sports Sci Med. 2002;1 (3):56-62.

16. Heiser TM, Weber J, Sullivan G, Clare P, Jacobs RR. Prophylaxis and management of hamstring muscle injuries in intercollegiate football players. Am J Sports Med. 1984;12(5):368-70.

17. Nosse LJ. Assessment of selected reports on the strength relationship of the knee musculature. J Orthop Sports Phys Ther. 1982;4(2):78-85.

18. Andrade MS, De Lira CA, Koffes FC, Mascarin NC, Benedito-Silva AA, Da Silva AC. Isokinetic hamstrings-to-quadriceps peak torque ratio: the influence of sport modality, gender, and angular velocity. J Sports Sci. 2012;30(6):547-53.

19. Rosene JM, Fogarty TD, Mahaffey BL. Isokinetic Hamstrings:Quadriceps Ratios in Intercollegiate Athletes J Athl Train. 2001;36(4):378-83.

20. Hiemstra LA, Webber S, MacDonald PB, Kriellaars DJ. Knee strength deficits after hamstring tendon and patellar tendon anterior cruciate ligament reconstruction. Med Sci Sports Exerc. 2000;32(8):1472-9.

21. Welsch MA, Williams PA, Pollock ML, Graves JE, Foster DN, Fulton MN. Quantification of full-range-of-motion unilateral and bilateral knee flexion and extension torque ratios. Arch Phys Med Rehabil. 1998;79(8):971-8.

22. Rousanoglou EN, Boudolos KD. Angle specificity of the knee extensor age-related profile in young female athletes. Int J Sports Med. 2008;29(1):66-9.

23. Bryant AL, Pua YH, Clark RA. Morphology of knee extension torque-time curves following anterior cruciate ligament injury and reconstruction. J Bone Joint Surg Am. 2009;91(6):1424-31.

24. Iossifidou AN, Baltzopoulos V. Inertial effects on the assessment of performance in isokinetic dynamometry. Int J Sports Med. 1998;19(8):567-73.

25. Dvir Z, Eger G, Halperin N, Shklar A. Thigh muscle activity and anterior cruciate ligament insufficiency. Clin Biomech (Bristol, Avon). 1989;4(2):87-91.

26. Brockett CL, Morgan DL, Proske U. Predicting hamstring strain injury in elite athletes. Med Sci Sports Exerc. 2004;36(3):379-87.

27. Rousanoglou EN, Karteroliotis K, Boudolos KD. A principal component analysis of sport-specific isometric evaluation. Isokinet Exerc Sci. 2006;14(3):261-7.

28. Rousanoglou EN, Herzog W, Boudolos KD. Moment-angle relations in the initial time of contraction. Int J Sports Med. 2010;31(9):651-5.

29. Hiemstra LA, Webber S, MacDonald PB, Kriellaars DJ. Hamstring and quadriceps strength balance in normal and hamstring anterior cruciate ligament-reconstructed subjects. Clin J Sport Med. 2004:14(5):274-80. 